Article

\title{
The Nexus between Socio-Ecological System, Livelihood Resilience, and Migration Decisions: Empirical Evidence from Bangladesh
}

\author{
Bishawjit Mallick ${ }^{(D)}$ \\ Chair of Environmental Development and Risk Management, Technische Universität Dresden, 01062 Dresden, \\ Germany; Bishawjit.Mallick@tu-dresden.de or Bishawjit.Mallick@googlemail.com; Tel.: +49-351-463-42590
}

Received: 19 May 2019; Accepted: 7 June 2019; Published: 17 June 2019

\begin{abstract}
This research aims to ascertain how, and to what extent, livelihood resilience influences migration decisions (to migrate or not to migrate) of people who live in vulnerable socio-ecological systems (SESs). To do so, first, the characteristics of different SESs are determined; secondly, livelihood resilience across the SESs are analysed; and finally, the influence of livelihood resilience on the 'migration decision' (i.e., to migrate or not to migrate) is explained. The explanation of migration is based on the patterns, location, purpose, scope, and extent of migration. This paper addresses these issues based on empirical evidence from five rural coastal communities in Bangladesh. Findings show that resilient people would like to stay put and the decision differs across SESs, for example, the majority of people living in salt-shrimp-dependent SESs intended to migrate in the future, whereas the majority of people living in rain-fed agriculture-dependent SESs preferred to not migrate. Thus, the ability to migrate is therefore not only dependent on economic capability but also on the socio-ecological context of the place in which people live.
\end{abstract}

Keywords: socio-ecological system (SES); livelihood resilience; migration decisions; (Non)Migration; Bangladesh

\section{Introduction}

A Socio-Ecological System (SES) is a system that can be defined at several spatial, temporal, and organizational scales and which may be hierarchically linked [1,2]. Usually, an SES is a dynamic and complex system with continuous adaptation of all the attributes [1-3]. The system can also be defined as the biophysical and social constructs (for example, within a coastal society) that regularly interact in a resilient and sustained manner and, therefore, as a set of critical resources (natural, social, and cultural) whose flow and usages are regulated by a combination of ecological and social systems $[1,3,4]$. The factors of the living environment (ecology and society) determine the category of 'resilience,' i.e., stability, adaptivity, or readiness [5]. T. Crane [6] reviews the importance of SES analysis and also suggests how empirical models of SESs can explain their interactions with livelihoods. The most robust livelihood systems are those with high resilience and low vulnerability [7], while the most vulnerable livelihoods demonstrate the opposite [8]. This is what the livelihood-resilience concept admits [9]. That is, livelihood resilience refers to an individual household's ability to absorb and recover from disturbances due to unexpected events and to adapt to the post-event conditions. Again, the adaptive dynamics are an inherent property of the SES, and there therefore exists a distinct interrelationship between SESs and livelihood resilience [10].

Livelihood resilience can be understood in terms of resilience capacity (e.g., absorptive, adaptive, and transformative) and by its relevance to different dimensions of livelihood conditions (e.g., social, economic, political, cultural, environmental, etc.). Ayeb-Karlsson and their colleagues [11] define 
livelihood resilience as 'the capacity of all people across generations to sustain and improve their livelihood opportunities and well-being despite environmental, economic, social, and political disturbances.' Therefore, understanding livelihood resilience helps to address the question of 'resilience of what and for whom' by focusing on the resilience of people's livelihood strategies [12,13]. Marschke and Berkes [14] claim that if a household's livelihood strategies and activities are better prepared for coping with and adjusting to the impacts of any disturbances caused by unexpected shocks, they can be considered resilient. They also claim that adapting to the changing conditions resulting from these disturbances forms the process of livelihood resilience building, and this process is mostly influenced by characteristics of the SES. The nature and extent of resilience or vulnerability is thus a product of different characteristics of the SES, i.e., the discussion of vulnerability is important in resilience understanding because the vulnerability emphasizes the ability of a system to deal with a hazard, absorbing the disturbances or adopting to it, and also helps in exploring the policy options for dealing with future uncertainty and changes in the system [15-18]. Thus, it explains that socio-ecological system resilience is about people and nature as an interdependent system [18], that influences the individual decision-making behaviour.

The Food and Agricultural Organization of the United Nations (FAO) has employed a quantitative method of calculating the 'resilience score' from different factors related to economic, social, and environmental resources that contribute to making households resilient to an unexpected shock [15]. This approach uses a systematic approach that assumes change is constant, and therefore that the livelihood resilience of an individual household can be described by the characteristics of stability, adaptive capacity, and readiness of the respective individual household to cope with an unexpected event. However, the status of livelihood resilience also depends on the available livelihood options and the ability to tackle risks. The ability to tackle risks also varies due to ex-ante and ex-post programme interventions taken by the household's internal resources and external institutions. This can be considered using two well-known frameworks, the process-oriented resilience framework and the outcome-oriented resilience framezork.

The process-oriented method considers the dynamic characteristics of the various factors when assessing livelihood resilience [19]. It considers a 4-R model (risk recognition, resistance, redundancy, and rapidity) for the resilience assessment of an individual household. Risk recognition refers to the degree of risk that an individual household recognizes during an event; resistance examines its capacity and strength to withstand the disturbances caused due to the event; redundancy refers to the extent of the substitution of resources in the aftermath of the event, whereas the rapidity explains the duration of time required for the individual household to obtain access to internal and external support.

The outcome-oriented resilience framework proposed by the Department for International Development (DFID) assesses the outcomes of livelihoods after an extreme event [20]. It is expected that, following any hazard, every individual household can be grouped into one of four outcomes: (i) bounce-back better refers to those households better able to handle future risks; (ii) bounce-back to status quo refers to a return to the pre-event status of the household; (iii) recovered describes a situation worse than the household's pre-event condition; and (iv) collapse refers to the worst-case scenario in which the household loses its capability to deal with future shocks. Process-oriented analysis describes the dynamic pattern in the resilience status of individual households, whereas outcome-oriented analysis explains the static dimension of the same. The process-oriented framework does not, however, explain the continuity between different stages in the aftermath of an extreme event, and it is therefore difficult to identify strategies from livelihood resilience alone, and thus difficult to assess the influence of livelihood resilience on migration decisions.

To 'opt to migrate' or 'opt not to migrate' is a livelihood decision. The reasons for one's 'opting to migrate' (hereafter 'migration') can also influence others' 'opting to not migrate' (hereafter 'non-migration'), even when all parties live within the same socio-ecological system (SES). However, this will not be so straightforward in every case, as the decision to migrate or not to migrate can be either voluntary or involuntary. Not every situation coerces migration, nor would everyone within a 
society wish to migrate, so the reasons for making a decision to migrate or not is very person-specific. A generalized explanation is therefore difficult to summarize. The purposes and causes of migration often vary, and it is difficult to know the root causes of population movement. The concept of 'pull' and 'push' factors is not new. The literature states that people choose migration as the last survival strategy to cope with livelihood struggles [21-23]. The Foresights annual report [24] has described five drivers that intrinsically influence migration decisions: social, economic, political, demographic, and environmental drivers. All five drivers are the integrated elements of an SES and influence livelihood resilience. It is projected that globally 10 million people may find themselves caught in vulnerable areas and unable to migrate due to resource constraints [22]. There is, however, no conclusive consensus on whether the reasons for migration are contraproductive for causes of non-migration. That is, the reasons for which an individual household decides to migrate can also be the reason for other individual households to opt for non-migration from the same place.

Further, the livelihood scenario varies across SESs, together with the factors that influence livelihoods as nested in an SES, and is differentiated by multilevel systems that provide essential services to individual households, such as supply of food, energy, and water [25,26]. All these characteristics of an SES determine the adaptive capacity of an individual household. It is therefore important to know how characteristics of an SES influence the livelihood resilience of people living within the respective SESs and thus their decisions regarding migration. It should also be noted here that the migration or non-migration decision, as an alternative adaptive strategy, directly contributes to livelihood resilience. The present research therefore aims to ascertain how, and to what extent, livelihood resilience influences the migration decisions (to migrate or not to migrate) of people living in a vulnerable socio-ecological system. The specific objectives are:

- to understand the dissimilarities of livelihood resilience across different socio-ecological systems;

- to explore the influences of livelihood resilience on migration decisions and its discrepancies across different socio-ecological systems;

- to analyse how the interrelationship between livelihood resilience and migration decisions can be useful for future climate-change adaptation policy planning.

To achieve these objectives, firstly an operational framework for livelihood resilience is developed (Figure 1), then the way in which livelihood resilience is influenced by the dynamic characteristics of an SES is analysed, and finally the influence of interrelationships between SESs and livelihood resilience factors on the 'migration decision' (i.e., to migrate or not) is explained.

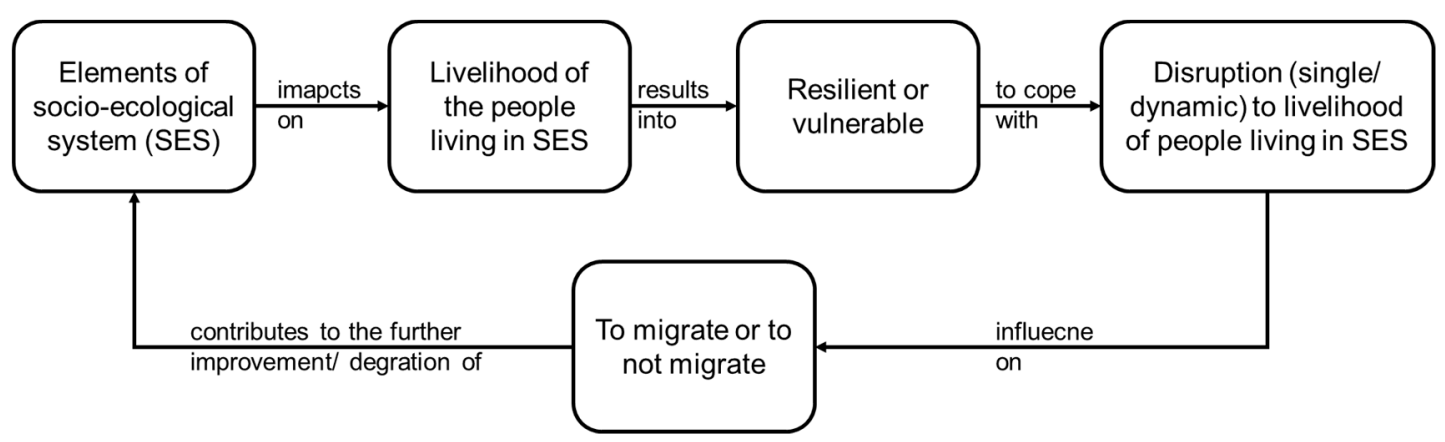

Figure 1. Conceptual framework between socio-ecological systems (SESs), livelihood resilience, and migration decision Source: Author's own illustration.

The conceptual framework (Figure 1) explains the nexus between livelihood resilience and migration decisions of households living in an SES. According to this framework, an SES is a set of critical resources (natural, socio-economic, and political) whose flow and use is regulated by a combination of ecological and social systems. 'Livelihood resilience' is a product of the SES in which people live, and the decision of migrating or staying put depends on how factors of the SES 
(ecological and social attributes) impact their livelihood resilience within a particular context of disruptions (environmental, social, political, or economic). It is assumed, in addition, that people opt for non-migration if their livelihood is resilient to external shocks. This assumption infers that resilience is an exogenous characteristic of the system, whereas coupled influence of both the endogenous and exogenous characteristics of the livelihood determine the livelihood resilience. Taking this limitation of analytical concept, in the course of the present research, the outcome-oriented approach of resilience analysis is employed, and empirical application of the conceptual framework presented in Figure 1 is undertaken. This paper addresses these issues based on empirical evidence from five rural communities in Bangladesh.

Section 2 describes the methodology, including the study area, the development of livelihood-resilience measurement, characteristics and types of socio-ecological systems, and migration patterns. Section 3 presents the results in light of the stated objectives. Section 4 discusses the results and Section 5 concludes the paper.

\section{Methodology}

\subsection{Southwest Coastal Communities in Bangladesh: Case Study Sites}

Bangladesh is ranked as the fifth-most climate-vulnerable country in the world due to its unique geographical location, high population density, and low climate resilience. Each year, the country is hit by at least one climatic event that displaces millions of people from their traditional habitat, while also adversely affecting their lives and livelihood. It is mostly those living in coastal areas who are affected. Again, as the Ganges-Brahmaputra-Meghna (GBM) delta constitutes a vulnerable social-ecological system [27], there is a relatively high potential for migration.

The Internal Displacement Monitoring Center (IDMC) has estimated that 4.7 million people were displaced due to national disaster in Bangladesh between 2008 and 2014 [28]. According to the current projection of the Intergovermental Panel on Climate Change (IPCC), more than a quarter of the country will be inundated, and more than 50 million people will be displaced by the end of this century. The population census of 2011 reports that $9.7 \%$ of the total population of Bangladesh are lifetime internal migrants and the calculations for 2010/2011 revealed an increase in emigration rates, with an approximate net migration of minus 12.5 people per 1000 for the Barisal Division, and minus 5.5 people per 1000 for the Khulna Division, meaning that more people are leaving these divisions than are coming in as migrants $[29,30]$. With regard to the people who decide not to migrate, especially in the coastal areas, the burning questions to investigate for future adaptation-policy planning in the country are: what happens to these people, how do they survive, and what are their strategic reasons behind their decision not to migrate?

Due to a lack of resources and time constraints, it was not possible within the scope of this study to conduct an empirical investigation of all the coastal regions of the country. Instead, a field study was conducted in five communities in the southwest coastal region. These communities were selected based on the extremity of their exposure to cyclones (Figure 2): two highly exposed communities (namely, Padmapukur village in the Uttarbedkashi union, Khulna district, and Chakdah village in the Mathureshpur union, Satkhira district), two moderately exposed communities (namely, Shovna village in the Shovna union, Khulna district, and Vabanipur village in the Islamkati union, Satkhira district) and one less-exposed community (namely, Panchkori village in the Nehalpur union, Jessore district). The general socio-demographic characteristics of these selected villages are presented in Table 1. 


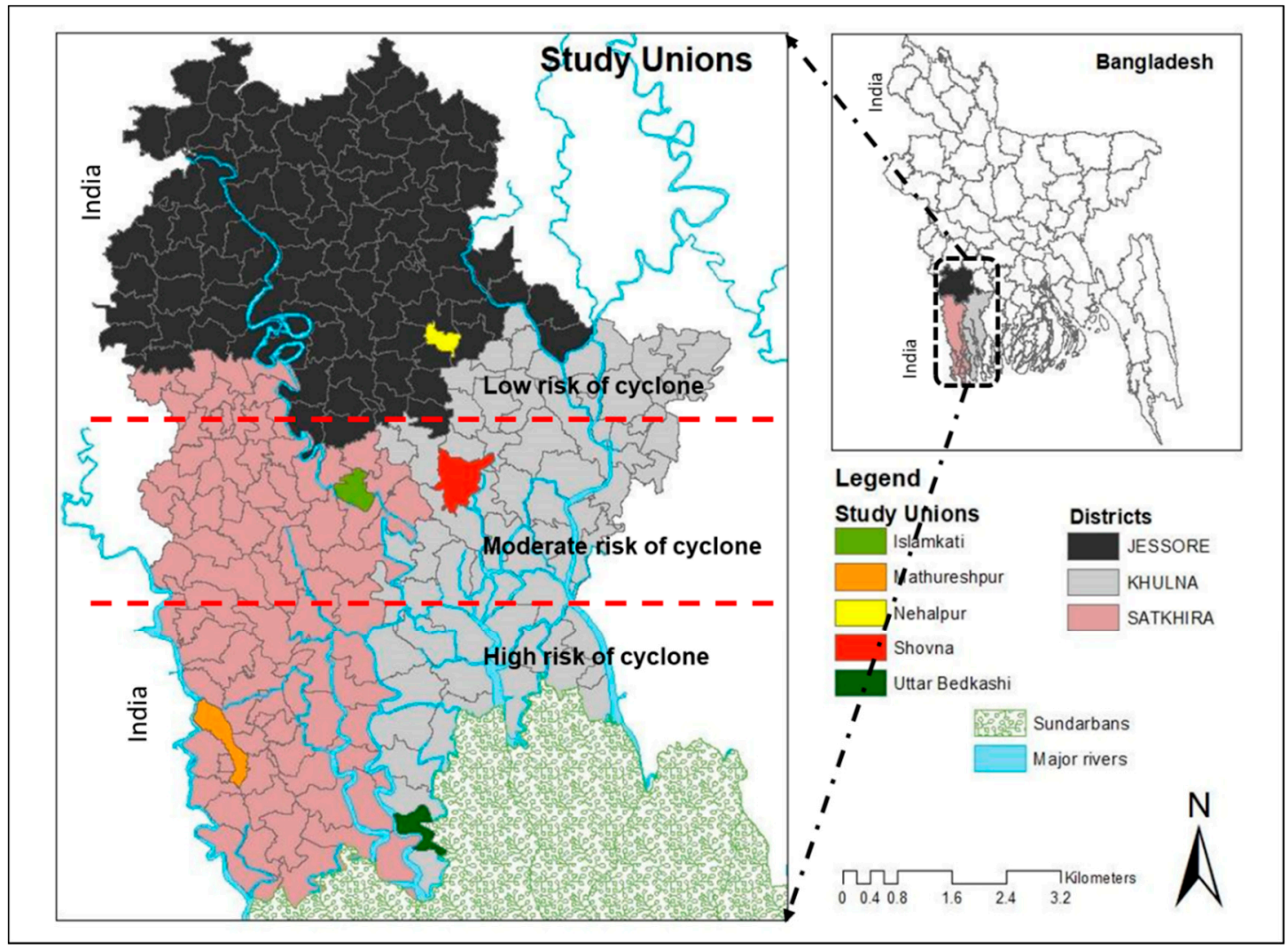

Figure 2. Communities studied. Source: Authors own illustration 2018.

Table 1. Socio-demographic characteristics of the villages studied.

\begin{tabular}{ccccccccc}
\hline District & Upazila & Union & Village & $\begin{array}{c}\text { Total } \\
\text { Population }\end{array}$ & $\begin{array}{c}\text { No. of } \\
\text { Households }\end{array}$ & $\begin{array}{c}\text { Average } \\
\text { Household Size }\end{array}$ & $\begin{array}{c}\text { Muslim } \\
\text { Religion (\%) }\end{array}$ & $\begin{array}{c}\text { Literacy } \\
\text { Rate }\end{array}$ \\
\hline \multirow{2}{*}{ Khulna } & Koyra & Uttar Bedkashi & Padmapukur & 1262 & 327 & 3.9 & 55.07 & 43.9 \\
\cline { 2 - 9 } & Dumuria & Shovna & Shovna & 8031 & 2024 & 4.0 & 61.51 & 53.3 \\
\hline \multirow{2}{*}{ Satkhira } & Kaliganj & Mathureshpur & Chakdah & 225 & 49 & 4.6 & 59.11 & 56.4 \\
\cline { 2 - 9 } & Tala & Islamkati & Vabanipur & 498 & 128 & 3.9 & 9.83 & 52.0 \\
\hline Jessore & Monirampur & Nehalpur & Panchkori & 4740 & 1137 & 4.2 & 53.08 & 45.1 \\
\hline
\end{tabular}

Source: Bangladesh Bureau of Statistics (BBS) 2011.

Table 1 shows that the selected villages are of different scale in terms of total population. Chakdah village has the smallest number of households (49) but the largest average household size (4.6), whereas Shovna village comprises the highest number of households (2024) with a moderate household size (4.0). Most of the villages have Muslim as the majority religion (varying between 53\% and 62\%), whereas Vabanipur is a Hindu majority village (92\% Hindu). There is no significant variation in the literacy rates across the villages.

\subsection{Data Collection}

A qualitative survey was conducted in the five villages described during March-April 2018. In particular, in-depth interview (ID) and group discussion (GD) methods were employed, with 38 individuals interviewed and 7 group discussion sessions conducted. Table 2 shows the distribution of the IDs and GDs across the studied villages together with the gender representation of the respondents. IDs were conducted with individuals using open-ended questions relating to the environmental and social factors that influence people's migration decisions and their livelihoods living in the SES. 
Table 2. Data collection methods and respondents' gender across sites.

\begin{tabular}{|c|c|c|c|c|c|}
\hline $\begin{array}{c}\text { Type of Data Collection } \\
\text { Method }\end{array}$ & $\begin{array}{l}\text { Padmapukur (\#, } \\
\text { male, female) }\end{array}$ & $\begin{array}{l}\text { Vabanipur (\#, } \\
\text { male, female) }\end{array}$ & $\begin{array}{c}\text { Chakdah (\#, male, } \\
\text { female) }\end{array}$ & $\begin{array}{l}\text { Shovna (\#, male, } \\
\text { female) }\end{array}$ & $\begin{array}{l}\text { Panchkori (\#, } \\
\text { male, female) }\end{array}$ \\
\hline $\begin{array}{c}\text { In-depth interviews } \\
\text { (38 individuals, } 24 \text { male, } \\
14 \text { female) }\end{array}$ & $\begin{array}{c}11 \text { individuals } \\
\text { ( } 7 \text { male, } 4 \text { female) }\end{array}$ & $\begin{array}{c}6 \text { individuals } \\
\text { ( } 3 \text { male, } 3 \text { female) }\end{array}$ & $\begin{array}{c}5 \text { individuals } \\
\text { (3 male, } 2 \text { female) }\end{array}$ & $\begin{array}{c}12 \text { individuals } \\
\text { (8 male, } 4 \text { female) }\end{array}$ & $\begin{array}{c}4 \text { individuals } \\
\text { ( } 3 \text { male, } 1 \text { female) }\end{array}$ \\
\hline $\begin{array}{l}\text { Group discussion } \\
\text { (7 GDs, } 79 \text { participants } \\
\text { total, } 55 \text { male, } 24 \text { female) }\end{array}$ & $\begin{array}{c}2 \text { GDs, } \\
\text { (23 participants, } \\
19 \text { male, } 4 \text { female) }\end{array}$ & $\begin{array}{c}1 \text { GD } \\
\text { (12 participants, } \\
7 \text { male, } 5 \text { female) }\end{array}$ & $\begin{array}{c}1 \text { GD }(10, \\
\text { participants, } \\
8 \text { male, } 2 \text { female })\end{array}$ & $\begin{array}{c}2 \text { GDs } \\
\text { (23 participants, } \\
14 \text { male, } 9 \text { female) }\end{array}$ & $\begin{array}{c}1 \text { GD } \\
\text { (11 participants, } \\
7 \text { male, } 4 \text { female) }\end{array}$ \\
\hline
\end{tabular}

Source: Author's own presentation based on 2018 field survey.

Group-discussion sessions were focused on: (i) socio-ecological characterization of the community; (ii) livelihood patterns and resilience statuses of people in the community in the aftermath of the last cyclone disaster; and (iii) general migration patterns and future tendencies. The group-discussion sessions lasted from two hours to three and a half hours, whereas the in-depth interviews lasted from thirty minutes to one hour. Both the group discussions and interviews were conducted in Bengali with the assistance of five research assistants, who were trained and guided accordingly by the author of this paper. With the due permission of the respondents and participants in the discussion sessions, all the data were recorded using an audiorecorder device, and later transcribed and translated into English.

\subsection{Analytical Approach}

This section explains the analytical framework used for characterization of SESs, livelihood resilience assessment, and the analysis of migration decisions.

\subsubsection{Characterization of Socio-Ecological Systems}

Socio-ecological systems are identified based on the data generated from in-depth interviews and group discussions conducted during the field survey. Some other studies of SESs have followed the same guidelines for defining an SES; for example, Crane (2010) [6], Fabinyi, Evans, and Foale (2014) [31], and Adams et al. (2018) [32]. The majority of the study area is classified as crop-cultivation area and aquaculture. Based on the dominant land use and proximity to rivers, other bodies of water, or mangroves, the selected villages are divided into four distinct SESs: irrigated agriculture, rain-fed agriculture, mangrove dependent, and salt-water shrimp. Once defined, these SESs were identified and mapped using ArcGIS software and analysis. During the field survey, the GPS coding of the selected villages was taken.

\subsubsection{Measurement of Livelihood Resilience}

This research considers the outcome-oriented approach of livelihood-resilience assessment [17], and concentrates on livelihood-resilience perspectives by asking: resilience of what, to what, and to what extent [33]? During group discussions, respondents were asked to describe the changed situation of their livelihoods after recent disasters had hit their locality. Most of them recalled cyclone Aila of 2009, the major extreme event of the recent past, having hampered or devastated their livelihood to a great degree. They mentioned that only a few of their villagers had improved their capital resources, while many were not able to return to their pre-cyclone-Aila status. Some had totally foundered. In order to obtain details about the outcome-oriented framework of resilience measures, i.e., (i) bounce back better, (ii) bounce back to the status quo, (iii) recovered, and (iv) collapse, the following questions were posed to participants: (i) how many of the community were in a different livelihood situation (using the outcome-oriented resilience framework), (ii) what were the main adaptation strategies, (iii) who had chosen migration (either temporary or permanent) as an adaptation strategy, and when, (iv) what type of migratory activity had been performed under normal circumstances, and finally (v) how would they describe their present capability to handle a future unexpected extreme event affecting their livelihood? Afterwards, the participants were asked to rank their livelihood as low, moderate, 
and moderately high resilient categories, asking the question: how do you rank your existing primary livelihood source against any kind of external shock or threat? The cumulative answer is presented at the union level. Most replied based on their present occupation; however, they prioritized the yearly rice-production options in their village as among the most important factors of livelihood resilience.

\subsection{3. (Non)Migration Infographic}

'Population migration' - whether temporary or permanent, internal or international, forced or voluntarily—is very complex to define. During GDs, participants were asked to describe the spatial distribution (i.e., within their own district, outside of their own district but within country, and outside of the country) of their seasonal and circular migration in order to understand the migration dynamics of the studied villages. It was difficult to identify patterns of permanent migration in the studied villages, but in most cases Hindu families migrated permanently to India, whereas other groups mostly migrated to the nearby big cities. Respondents were asked to categorize the reasons for migration into economic, social, or environmental factors, and these reasons were presented across categories of gender and age. Finally, respondents were asked about their aspirations and capabilities regarding future migration decisions (migration or non-migration).

\section{Results}

Based on the analytical framework described in Section 2, this section presents, firstly, the identified SES characteristics; secondly, the livelihood-resilience patterns across the SESs; and, finally, the interrelationship between livelihood characteristics and migration decisions.

\subsection{Characteristics of Socio-Ecological Systems}

A summary of the SES characteristics is presented in Table 3 and Figure 3. Two major types of aquaculture practice, shrimp and Golda (a local variety of river prawn), are observed in the studied villages (see Figure 3B). The extent of these practices depends upon and varies according to the availability of saline water, which is itself dependent on proximity to rivers. Two out of the five studied communities have no salinity problems and therefore more opportunity for rice production, which helps in keeping the level of poverty low in these villages. Flooding is identified as the major hazard, usually occurring during monsoons due to heavy rainfall and long-standing water-logging problems.

Table 3. SES characteristics as determined by the field survey.

\begin{tabular}{lccc}
\hline SES Type & Studied Community & Environmental Attributes & Social Attributes \\
\hline Irrigated agriculture & Bhavanipur & $\begin{array}{c}\text { 2-fold rice yield, no salinity, water-logging, } \\
\text { floods, not close to the river }\end{array}$ & $\begin{array}{c}\text { One in five is poor, but less } \\
\text { religious conflict. }\end{array}$ \\
\hline Rain-fed agriculture & Shovna & $\begin{array}{c}\text { 3-fold rice yield, no salinity, no extreme } \\
\text { events, stands on river bank }\end{array}$ & $\begin{array}{c}\text { One in seven is poor, but almost } \\
\text { no religious conflict. }\end{array}$ \\
\hline Mangrove-dependent & Padmapukur & $\begin{array}{c}\text { Single rice yield, salinity, cyclones, floods, } \\
\text { river-bank erosion, mangrove forestry } \\
\text { periphery, stands on river bank }\end{array}$ & $\begin{array}{c}\text { One in three is poor, but almost } \\
\text { no religious conflict. }\end{array}$ \\
\hline Salt-water shrimp & Chakdah & $\begin{array}{c}\text { Single rice yield, salinity, cyclones, floods, } \\
\text { not close to the river }\end{array}$ & $\begin{array}{c}\text { One in three is poor, and highest } \\
\text { level of religious conflict. }\end{array}$ \\
\hline Irrigated agriculture & Panchakorai & $\begin{array}{c}\text { 2-fold rice yield, salinity, water-logging, } \\
\text { floods, stands on the river bank and tidal } \\
\text { river management project ongoing. }\end{array}$ & $\begin{array}{c}\text { One in five is poor, } \\
\text { and moderate level of religious } \\
\text { conflict. }\end{array}$ \\
\hline
\end{tabular}

Source: Field survey 2018.

It is observed that people living in Shovna village have the opportunity to produce rice three times in the year (see Figure 3A). The villagers of Shovna mentioned that sources of fresh water are among the main reasons for threefold rice production. One of the major reasons is that this SES is hardly affected by any hazards (see Figure 3C). They are free from saline water and have adequate irrigation facilities, and can therefore produce Aus, Aman, and Boro rice, creating employment opportunities for 
the wage-earner locally and thus reducing their dependency on seasonal migration. It is mostly those who are dependent on daily labour and work inside the community in farming or fishing who migrate seasonally, particularly during the Boro rice season. Such labourers are used to going for three months to the Gopalgonj, Madaripur, or Faridpur districts (northeast of Khulna district) to harvest Boro rice. They take rice instead of money in the form of cash as the mode of payment for their labour, bringing the collected rice back to their homes. Many seasonal migrant families reported that, with the rice received, their family can sustain at least 3-6 months, depending on the number of family members.

The majority of the people living in salt-water-dependent SESs (i.e., Chakdah village, on the border with India) reported the existence of more religious conflict compared to other SESs (Figure 3E). Interestingly, people living in a mangrove-dependent community reported less religious conflict than in two other studied communities, one of which has a Hindu majority, the other a Muslim majority. Both of these are dependent on an irrigated-rice production system.

More poor people live in the mangrove-dependent community (i.e., Padmapukur) than others, whereas a smaller number of poor people live in a rain-fed agriculture SES, i.e., in Shovna. People living remote from the major cities are relatively poor in general as they cannot mobilize resources properly, and they therefore face frequent economic losses to productivity (Figure 3D). They furthermore remain poor as they have very limited options for diversifying their livelihoods. In addition, almost everyone in Chakdah village thinks they face border problems between Bangladesh and India, while none in the other studied villages mention such problems.
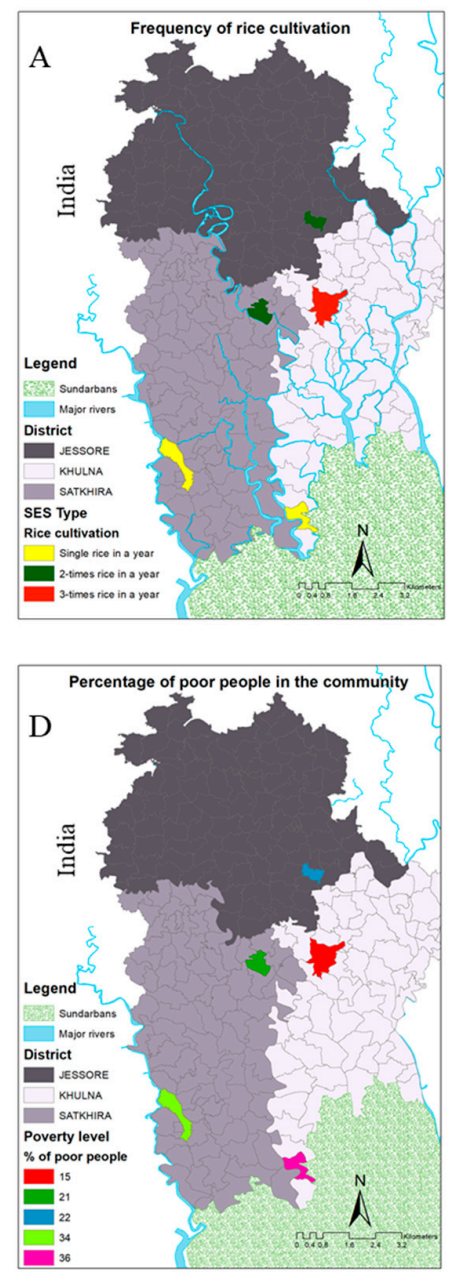

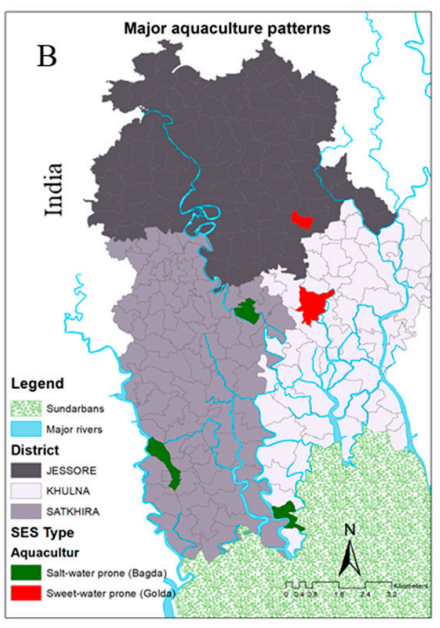

\section{Findings}

- Production of rice has been increased but not in all places.

- Shrimp-farm is source of social conflicts.

- Flood usually happens during monsoon due to heavy rainfall and long-standing waterlogging problems.

- Border regions have more religious conflicts.

- Less number of poor people in the community indicates diversified livelihood options.
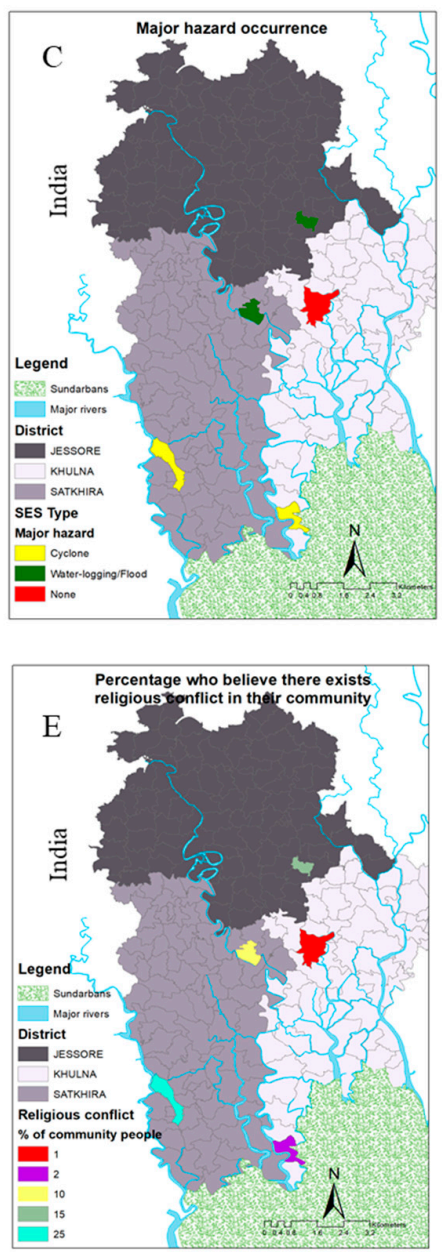

Figure 3. Socio-ecological system characteristics of the studied villages. Source: Author's presentation based on the 2018 field survey data. 


\subsection{Livelihood Resilience across SESS}

Farming and fishing are identified as the main livelihood sources in the studied villages, followed by the wage-earning or so-called daily-labour group as a third main source of employment. This indicates that the majority of livelihood opportunities are dependent on natural resources. Farming and fishing cover about $50 \%$ to $70 \%$ of the listed livelihoods in each of the studied communities. The percentage of fishing is highest at Padmapukur village in the Uttar Bedkasi union (49\%), while the percentage of farming is highest at Chakdah village in the Mathureshpur union (52\%). Farming or fishing is the main source of livelihood in each community, but wage earning is the second source of livelihood in each, with the highest percentage at Vabanipur (32\%). Fish trading, business, livestock rearing, remittance, and additional sources of livelihood appear to a very minimal degree.

Participants mentioned that the main challenge of living in mangrove-dependent SESs was that they had hardly any chance to farm rice, despite it being their staple food. They were therefore dependent on purchasing rice. They considered farming salt-water shrimp or any kind of prawn or fish a better source of earning more money, but the profit from shrimp farming was dependent on the scale of the farm, quality of production, and disease prevention. Most of those dependent on shrimp farming were therefore unable to recover from the shock derived from cyclone Aila and lost their livelihood, consequently being forced to migrate away from their communities (to nearby cities or even to India) for an alternative income source.

The level of resilience of these livelihood categories is analysed by characterizing the socio-ecological systems, and presented according to the outcome-oriented livelihood resilience framework in Figure 4. Based on the framework employed and the statements of participants, Figure 4 shows that only $6 \%$ of the people in their communities were able to bounce back better following cyclone Aila in 2009, and that they were living in largely agricultural SESs. Nobody living in a salt-water-shrimpor a mangrove-dependent SES could bounce back better after cyclone Aila. The livelihood condition in a mangrove-dependent SES is again more vulnerable than a rain-fed agricultural SES (Figure 4). It was even reported during discussion that people living in an irrigated-agricultural SES or a rain-fed agricultural SES had faced less trouble in returning to their pre-event condition.

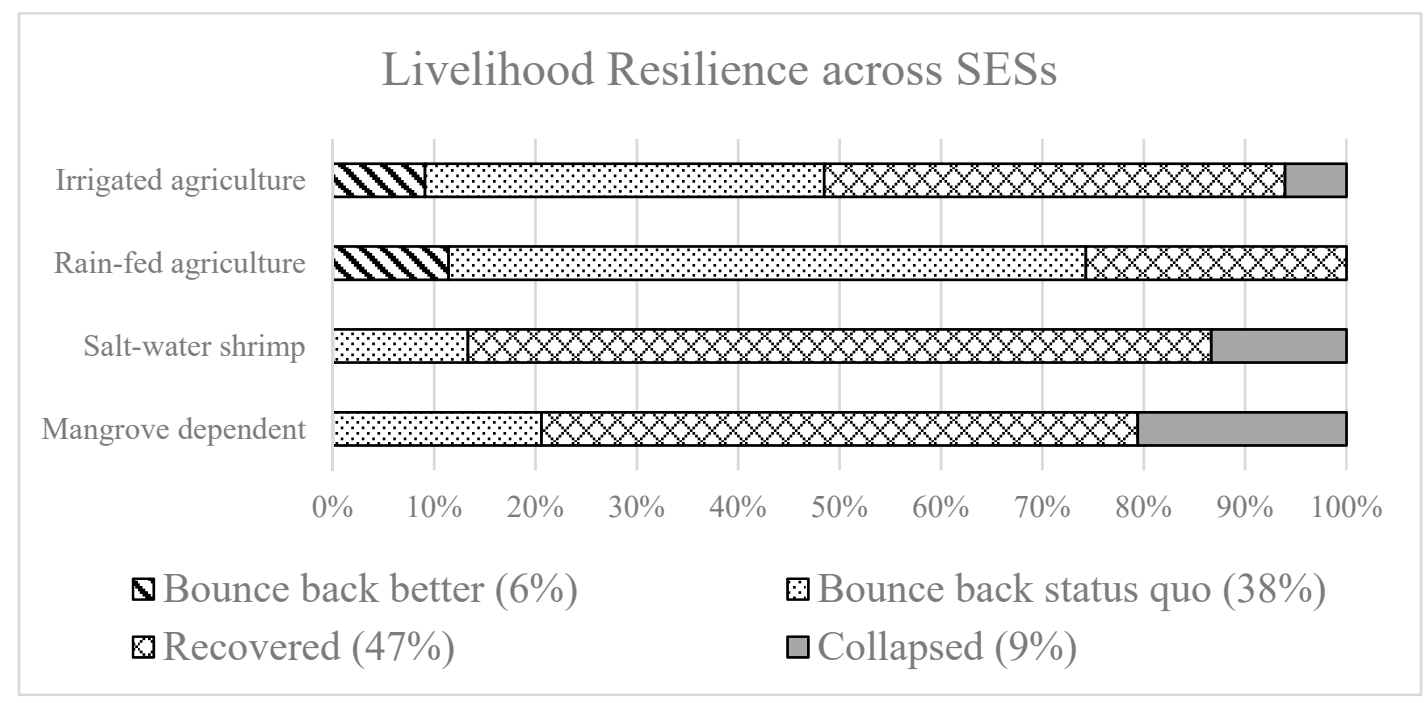

Figure 4. Opinion of interview and group-discussion participants on 'livelihood resilience' across SESs. Source: Field survey 2018.

There was no 'collapsed livelihood resilience' case in rain-fed agriculture, but 'bounce back status quo' shows the highest percentage and 'bounce back better' the lowest percentage. The majority of the 'recovered' resilience groups lived in salt-water shrimp SESs. The reasons for their recovery mentioned during discussion were twofold: firstly, having been inundated for several months, they could fish in 
the canals and rivers, and secondly, ample relief and reconstruction support from both the government and non-government sectors was made available.

\subsection{Present (Non)Migration Infographic across SESs}

\subsubsection{Pattern-Seasonal, Circular, and Permanent}

There was evidence of seasonal and circular migration in all kinds of SES. Seasonal migrants are those who migrate once or twice at a particular period of the year, usually when there is no available employment in their native communities, whereas the circular migrants are those who migrate regularly to earn money so that their families can stay in their place of origin. Both seasonal and circular migration are strategies for staying in one's place of origin in the long term. The results of the field study show that a rain-fed agriculture SES includes fewer people practising temporary migration, whereas those from a salt-water shrimp SES practise comparatively more seasonal migration.

The studied salt-water shrimp SES is located in a border region (Bangladesh-India), where different kinds of opportunity to be involved in sustaining one's livelihood are available. During discussions and even in in-depth interviews with the people living in this area, it was revealed that young people (mainly those who have dropped out of education) were involved in illegal markets, trafficking cattle, clothing, alcohol, drugs, rice, and lentils, for example, and then selling it on the black market. Some travelled illegally to India and worked there for two to six months in different sectors, from brick-field to hawker businesses. As the culture and customs of the Indian state of West Bengal is not different to those of Bangladesh, it is easy for them to assimilate themselves into society there even without a legal passport. In addition, they were well connected socially to their destination in India, and could therefore easily handle any legal action taken against them, should any occur.

In discussions on permanent migration with people living in the rain-fed agriculture and irrigated-agriculture SESs, merely five to ten families were reported as having permanently migrated from their villages during the previous five years, equal to less than $1 \%$ of their communities. They tended not to mention migration as a regularly occurring event, as those who migrated permanently had no option to stay. Rather than economic crisis, they were mostly involved in political conflict and troubled by legal actions, and therefore had to leave their place of origin. According to the perception of the discussants, those who permanently migrated from their villages usually went to India or to Dhaka. Once again, those who had permanently migrated from Padmapukur (a mangrove-dependent SES) after cyclone Aila had settled down in major cities, mainly in Khulna and Dhaka. However, the rates of permanent migration in the studied SESs were not so high, with around $2 \%$ of all households in the villages having migrated during the last five years.

Historically, the people in Chakdah village (a salt-water shrimp SES) travelled and worked illegally in India, before border restrictions became stricter. Differing from other studied SESs, however, they no longer have the confidence to travel to and work illegally in India without having any strong social networks in place. Usually, those who used to undertake seasonal migration to India have relatives there who arranged work for them. Some discussants reported that a few of them used to acquire tourist visas and worked in India. This began when the Indian High Commission decentralized their consulate services to a divisional level in Bangladesh, allowing people to acquire multiple-entry visas for longer periods of time. On the other hand, earnings in India are comparatively better than in Bangladesh due to divergence in the value of the currency of payment.

\subsubsection{Immigration}

Interestingly, discussants of the mangrove-dependent SES reported that, after Aila, at least five families had immigrated to their communities, and had been living on the embankments. They immigrated to the locality while they thought there were opportunities for fishing in Sundarbans and receiving support from the ongoing governmental and nongovernmental rehabilitation projects. Some emigrants in this SES sought to hide themselves from the legal authorities in Padmapukur village, 
which is not easily accessible from the local police station. They could therefore live comfortably here while fishing in Sundarbans or nearby rivers. No other immigrant families were reported in discussions with the other four studied villages.

\subsubsection{Gender Dimensions}

It is mainly the male population who migrate seasonally, with hardly any female examples reported in the discussions. The reasons are threefold: (i) women take care of family members and household activities, (ii) accommodation in migrant destinations is insecure and women are exposed to sexual harassment, and (iii) women are paid less in almost all sectors of employment. Women who are forced to work outside their families usually work within their communities, mainly in fish-larva collection, earth-work for road reconstruction, as factory labour, or exceptionally as maid-servants. Women from the Panchkori village (irrigated-agriculture SES) used in particular to work in the cement and Bidi factories in Nowapara municipality, whereas the women in Shovna village (rain-fed agriculture SES) mostly worked as maid-servants (if required). Again, women living in the mangrove-dependent SES collected fish larva (prawn and shrimp) in the rivers and were also employed in earth-work for reconstruction of the embankment and roads in their locality. Some girls in this area went to Dhaka to work in garment production. Women living in the border communities (Chakdah village) were involved in peddling Indian textiles and ornaments in nearby villages. Hardly any of them practiced seasonal or temporary migration. In addition, the discussants mentioned cultural and religious customs and obligations that could not be maintained after migration as one of the major issues preventing women and family members from migrating.

\subsection{Livelihood Resilience-Migration-SES}

Findings show that, overall, one in five of the discussants would like to migrate from their communities in the near future. Figure 5 shows that resilient people (bounce back better) are less likely to migrate in the future, whereas among all other categories of livelihood resilience, a majority of the collapsed category intended to migrate in the near future. The majority of people living in salt-water-shrimp-dependent SESs intended to migrate in the future. The studied villages can be ranked according to aspiration for future migration thus: Chakdah $\rightarrow$ Padmapukur $\rightarrow$ Vabanipur $\rightarrow$ Panchkori $\rightarrow$ Shovna, i.e., the majority of people living in Chakdah village aspire to migrate in the near future. Not only SES characteristics, but also the proximity to India, plays a vital role in their migration decisions.

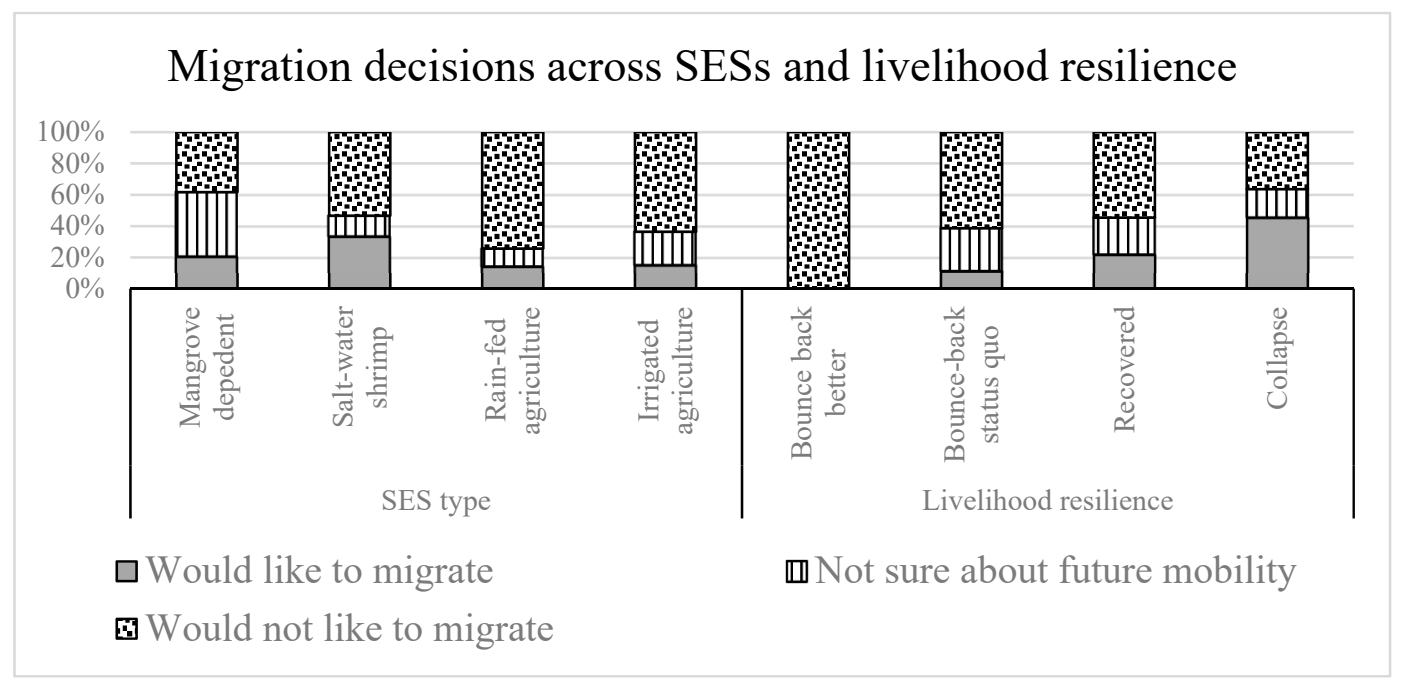

Figure 5. Future migration in the context of livelihood resilience and SES characteristics. Source: Field survey 2018. 
Most people in this village want to migrate to India, whereas a much smaller number of respondents in the other four villages wanted the same. They mostly favoured migration to the nearby cities and villages, where they will face fewer hazards while enjoying more income opportunities. The result is that people who are mostly dependent on mangrove-forest and shrimp farming were less resilient and would like to migrate in the near future, whereas people living in rain-fed or irrigated-agriculture SESs were more confident of not migrating.

The findings show that most of the people consulted have experienced climatic events constantly from a very early age, and are mostly used to coping with them. They therefore really do not think much about extreme events and are even unworried about climate change and climate migration. Dependency on natural resources is another reason behind non-migration. Land is something on which people depend, and on which people live. People who own land believe that if they migrate to other areas, they will have nobody to guard their land, and subsequently decide not to migrate. This finding supports the concept of 'place attachment' [22,34,35]. Moreover, these people usually have social decision-making power. Being affluent, they used to maintain a patron-client relationship within their communities [36]. They help poor families in difficult times, strengthening their communal ties and social protection, and inhibiting their willingness to migrate. In addition, greater rice production, less conflict, and social connectedness play vital roles in diversifying livelihood and reduce the ratio of poor people in the community, which ultimately helps to keep people in their place of origin.

\subsection{Future (Non)Migration: Aspiration vs. Capability}

Aspirations to migrate do not always ensure that people can realize their migration. Non-migrants can therefore be categorized into two groups: one group that has the capability to migrate but chooses not to migrate, and another group who are unable to realize migration due to constraints in resources (economic, social, and cultural). The latter is termed a 'trapped population' in the literature $[22,24,35-38]$. The aspiration to migrate and its realization thus depend on the level of livelihood resilience, which is also characterized by opportunities offered in the respective SES.

While discussing their capability to realize future migration, most of those living in rice-fed agriculture and irrigated-agriculture SESs were confident that they could accomplish their migration desires if it were required of them. In the case of mangrove-dependent SESs, a large number of people reported their inability to emigrate from their community. The reasons mentioned were: (i) most of them are usually living from hand to mouth, (ii) most of them depend on natural resources and therefore cannot save enough to support themselves in a future crisis, (iii) they were living in very remote places, and the cost of migration would therefore be beyond their capacity, and (iv) most of them had nobody in the destination places who can help them to obtain work opportunities or find housing facilities to live in. Most of those living in a salt-water shrimp SES also thought themselves unable to realize their migration aspirations. The reasons for their inability are almost the same as the people living in mangrove-dependent SESs, except that they have an additional problem related to ongoing tensions on the border between India and Bangladesh. Because most of the people in this SES are involved in illegal export-import activities, they have to bribe border police in both countries, reducing the margin on their profit, with the result that they were ultimately unable to save enough to handle future shocks. They had even had to face police harassment several times a year, which also incurred substantial monetary losses. Some families left this village permanently due to continuous harassment by the police, border security, and local politicians, leaving resources and houses behind unsold. In every studied SES, some people were unconvinced about their ability for future migration, as they did not know to where they could migrate permanently together with their whole family. 


\section{Discussion}

\subsection{Reflections on the Conceptual Model}

It is nevertheless evident that every migration process starts with a 'push factor' in the society of origin and ends with a 'pull factor' in the destination society [39]. 'Push factors' are the disturbances to one's normal livelihood; 'pull factors' are therefore the attractions and opportunities for one's livelihood at the destination. This means that susceptibility to being vulnerable or resilient to a specific unexpected occurrence within the normal livelihood conditions (e.g., environmental hazards, social or political conflict, economic crises) can influence the decision to migrate or not. This is the question of the vulnerability or resilience to a specific unexpected situation. However, the individual condition of 'being vulnerable' or 'being resilient' to a specific hazard is also an outcome of the environment and society in which the individual lives, i.e., the conditions of the socio-ecological system (SES). An SES is a complex system that integrates both humans and the natural environment and manifests the interactions between them [1,2]. The dynamic characteristics of an SES compose the resilience and vulnerability statuses of an individual and shape the overall livelihood strategies. Every individual living in an SES adopts strategies to cope with adverse and unexpected situations [31,40]. A decision to migrate or not to migrate is one strategy available to combat unexpected disturbances to one's normal life, and such a decision may depend upon the status of one's livelihood resilience or vulnerability. In this context, this paper addresses the relationship between livelihood resilience and the migration decisions of people living in different socio-ecological systems. It is observed in the analysis (Sections 3.2 and 3.5) that SES characteristics influence the livelihood opportunities for the people living in the respective SESs, and that SES determines the level of livelihood resilience of the people [8].

This study considers the outcome-oriented resilience framework in assessing the livelihood resilience of the people in the face of cyclone Aila and explores that nobody living in a salt-water-shrimpor a mangrove-dependent SES could bounce back better after the event. This reflects the knowledge base of SES that describes that the nature and extent of being resilient or vulnerable for an individual is a product of the influencing factors of the SES in which the individual is embedded [1,2]. Compared to all other SES, the livelihood condition in a rain-fed agricultural SES is better than any other studied SESs. These findings suggest to reduce the dependency on salt-water shrimp farming and to promote more opportunities for rice production or a mixed culture of fish and rice [41]. Again, it was evident that resilient people would like to stay put, whereas the majority of the collapsed category intended to migrate in the near future, i.e., the majority of people living in salt-water-shrimp-dependent SESs intended to migrate in the future, whereas the majority of people living in rain-fed agriculture-dependent SESs preferred to not migrate. In a nutshell, this study results into how and to what extent the SES characteristics had influenced the individual/community livelihood resilience aftermath of a cyclone, and therefore, the outcome of the livelihood resilience explains the non-migration/migration pattern in the studied SESs. This reflects perfectly on the conceptual framework described in Section 2, and thus acknowledging to some extent how the interdependencies analysis between SESs and livelihood resilience is important in migration studies.

\subsection{Drawback and Critiques}

This research contributes to the understanding on the influence of livelihood resilience on individual decision-making for adaptation strategies, particularly for migration decisions in the face of unexpected hazardous and extreme events. There are different frameworks for analyzing both SESs [1] and livelihood resilience [9], but it was not possible under this study to test all of these frameworks. Rather, this study considers a data-generated method for analyzing SES characteristics that has advantages as well as drawbacks. Firstly, this method only provides an overview of the environmental and social characteristics of the system and does not necessarily describe the dynamics of the changes that happened to the system in the course of time. Therefore, it does not consider also the dynamic characteristics of livelihood resilience as well as the migration decisions (migration and 
non-migration), pattern, extent, and scope over the time. Recently, scientists have been incorporating technology in understanding the SESs by employing the Social- Ecological-Technical System (SETS) approach [42,43]. This study also does not consider the contribution of the technologies to the changes in an SES, which refers to the importance of the impacts of technology on the resilient capacity of the individual or the community. Therefore, further research is needed to investigate how the understanding of a Social-Ecological-Technical System (SETS) approach can be incorporated into human migration analysis in the context of climate change adaptation planning.

If the goal was to analysis how the livelihood resilience and migration decisions have changed over time, it is required to repeat the same approach for two different points in time. Additionally, this method of SES characterization does not consider the sustainability aspects of a system that ensures the availability of sustainable livelihood resources [44,45]. Some indicators of building livelihood resilience processes were needed to include in the assessment [14]. Again, this study considers only the outcome-oriented livelihood resilience assessment approach, which also does not cover the dynamic characteristics of livelihood resilience and, therefore, it was also not possible to depict the migration (pattern, extent, or scope) in the course of time.

\section{Conclusions}

Overall, an SES is a complex system that integrates both nature and people. The dynamic characteristics of an SES shape the overall livelihood strategies of individuals living within it. Usually, every individual tries to improve their quality of life and adopts strategies that help to cope with adverse situations facing their livelihood. Deciding to migrate or not to migrate is one such livelihood strategy to combat unexpected disturbances to one's normal life.

Again, the study finds that seasonal and circular migration are methods for deciding long-term non-migration from the place of origin. This has been addressed as 'trans-local' livelihood in other research [46-48]. Non-migration in the face of translocal livelihood explains the situation of a society in which some people regularly or seasonally migrate for principally economic purposes. Such family-member seasonal or translocal mobility builds the household's capacity to cope in the face of an adverse livelihood situation [47-49]. However, it remains unexplored how such translocal mobility of household members contributes to the long-term non-migration of other members of the household, and how it reduces the household vulnerability in general as well as constituting the overall 'livelihood resilience' of the household across SESs.

It was evident that most permanent migration occurred due to socio-political conflicts rather than environmental problems, which raises the importance of promoting good governance and human-rights programs. Findings suggest that permanent migration is not a solution for sustainable development; it is rather more important to promote and implement development programmes that will be accepted by local people [50]. This paper thus indicates that the locational suitability of an SES plays a vital role in the economic progress of a community. Mangrove-dependent SESs, for instance, were not successful enough to recover losses incurred due to cyclone Aila. The ability to migrate is therefore not only dependent on economic capability, but also on the socio-ecological context of the place in which people live.

Furthermore, the historical pattern of migration and livelihood sources also influence future migration dynamics, where the SES characteristics and local political environment play vital roles requiring more detailed research. Findings also indicate variation by gender regarding migration decisions across the SESs, which is another aspect that requires further investigation, taking social norms, culture, and livelihood into consideration.

Finally, given the role of SES and livelihood resilience in migration discussion as presented in Section 3.3, this study recommends that the climate change adaptation policies should seek to reduce the livelihood vulnerability and improve the well-being of the people living at risk. In the context of the studied SESs, it includes: (i) promoting agricultural adaptation (i.e., conversion from shrimp to rice production) to reduce the livelihood stresses which drive migration; (ii) creating alternative livelihood 
options, (i.e., establishment of local industries) to enhance resilience and adaptive capacities of the households. It can be done by skill development training, particularly for the women and older people, to improve the likelihood of decent working opportunities; and (iii) finally, enhancing community cohesion by improving the risk-management capacity of the community and voluntary organizations, social groups, and associations.

The methodological approach and conceptual framework used in this research can be employed in different regions sharing similar socio-environmental characteristics, providing an added value to the understanding the interrelationship between migration, livelihood resilience, and socio-ecological systems.

Funding: This research was funded by the Open Topic Post-Doc scheme of Technische Universität Dresden, grant number F-003661-553-Ü1G-1212042.

Acknowledgments: This study would not have been possible without the dedicated effort of all enumerators (Md. Afirul Islam, Bangkim Biswas, Fatema Tuz Zohara Rumki, Tunazzina Islam Diya, and Saikat Mondol) involved in the data collection, the local respondents, who provided the information. I am also thankful to the local collaborators in Bangladesh, particularly Dr. Nadiruzaman of the Independent University of Bangladesh (IUB) and Dr. Md. Monirul Islam of the Department of Fisheries at the University of Dhaka, Bangladesh, for their continuous support in organizing meetings, workshops, and scientific collaboration during the field work. I would also like to thank the logistical support provided by the Satkhira Unnayan Sangstha (SUS) and Coastal Research Foundation (CRF) during field work. The financial support was received from the OTPP project of the Technische Universität Dresden, F-003661-553-Ü1G-1212042, titled 'Non-migrability: Non-Migration of People at Risks in the Context of Social and Economic Vulnerability'.

Conflicts of Interest: The authors declare no conflict of interest. The funders had no role in the design of the study; in the collection, analyses, or interpretation of data; in the writing of the manuscript, or in the decision to publish the results.

\section{References}

1. Binder, C.R.; Hinkel, J.; Bots, P.W.G.; Pahl-Wostl, C. Comparison of Frameworks for Analyzing SocialEcological Systems Comparison of Frameworks for Analyzing Social-Ecological Systems. Ecol. Soc. 2013, 18, 26. [CrossRef]

2. Ostrom, E. A General Framework for Analyzing Sustainability of Social-Ecological Systems. Sceince 2009, 325, 419-423. [CrossRef] [PubMed]

3. McGinnis, M.D.; Ostrom, E. Social-Ecological System Framework: Initial Changes and Continuing Challenges. Ecol. Soc. 2014, 19, 30. [CrossRef]

4. Turner, B.L., II; Kasperson, R.E.; Matson, P.A.; McCarthy, J.J.; Corell, R.W.; Christensen, L.; Eckley, N.; Kasperson, J.X.; Luers, A.; Martello, M.L.; et al. A Framework for Vulnerability Analysis in Sustainability Science. Proc. Natl. Acad. Sci. USA 2003, 100, 8074-8079. [CrossRef] [PubMed]

5. Kerner, D.; Thomas, J. Resilience Attributes of Social-Ecological Systems: Framing Metrics for Management. Resources 2014, 3, 672-702. [CrossRef]

6. Crane, T.A. Of Models and Meanings: Cultural Resilience in Social-Ecological Systems. Ecol. Soc. 2010. [CrossRef]

7. Mavhura, E. Applying a Systems-Thinking Approach to Community Resilience Analysis Using Rural Livelihoods: The Case of Muzarabani District, Zimbabwe. In International Journal of Disaster Risk Reduction; Elsevier Ltd.: Oxford, UK, 2017; pp. 248-258.

8. Jurjonas, M.; Seekamp, E. Rural Coastal Community Resilience: Assessing a Framework in Eastern North Carolina. Ocean Coast. Manag. 2018, 162, 137-150. [CrossRef]

9. Quandt, A. Measuring Livelihood Resilience: The Household Livelihood Resilience Approach (HLRA). World Dev. 2018, 107, 253-263. [CrossRef]

10. Cote, M.; Nightingale, A.J. Resilience Thinking Meets Social Theory: Situating Social Change in SocioEcological Systems (SES) Research. Prog. Human Geogr. 2012, 36, 475-489. [CrossRef]

11. Ayeb-Karlsson, S.; Tanner, T.; van der Geest, K.; Warner, K. Livelihood Resilience in a Changing World—6 Global Policy Recommendations for a More Sustainable Future; UNU-EHS Working Paper; UNU-EHS: Bonn, Germany, 2015. 
12. Schanze, J. Resilience in Flood Risk Management-Exploring Its Added Value for Science and Practice. E3S Web Conf. Flood Risk Management 2016, 7, 08003. [CrossRef]

13. Jones, L.; Tanner, T. Subjective Resilience: Using Perceptions to Quantify Household Resilience to Climate Extremes and Disasters. In Regional Environmental Change; Springer: Berlin/Heidelberg, Germany, 2017; Volume 17, pp. 229-243.

14. Marschke, M.J.; Berkes, F. Exploring Strategies That Build Livelihood Resilience: A Case from Cambodia. Ecol. Soc. 2006, 11, 42. [CrossRef]

15. FAO. Measuring Resilience: A Concept Notes on the Resilience Tool; FAO: Rome, Italy, 2010.

16. Berkes, F. Understanding uncertainty and reducing vulnerability: Lessons from resilience thinking. Nat. Hazards 2007, 41, 283. [CrossRef]

17. Holling, C.S. Resilience and stability of ecological systems. Annu. Rev. Ecol. Syst. 1973, 4, 1-23. [CrossRef]

18. Walker, B.; Holling, C.S.; Carpenter, S.R.; Kinzig, A. Resilience, adaptability and transformability in social-ecological systems. Ecol. Soc. 2004, 9, 5. [CrossRef]

19. Forgette, R.; Van Boening, M. Assessing Community Socio-Economic Resilience to Natural Disasters. SERP Research Report. 2010. Available online: http://www.olemiss.edu/depts/economics/serri/serpfactsheet.pdf (accessed on 25 March 2012).

20. DFID. Defininf Disaster Resilience: DFID Approach Paper. London. 2011. Available online: https: //www.fsnnetwork.org/sites/default/files/dfid_defining_disaster_resilience.pdf (accessed on 14 April 2012).

21. McLeman, R.; Hunter, L.M. Migration in the Context of Vulnerability and Adaptation to Climate Change: Insights from Analogues. Wiley Interdiscip. Rev. Clim. Chang. 2010, 1, 450-461. [CrossRef]

22. Black, R.; Bennett, S.R.G.; Thomas, S.M.; Beddington, J.R. Climate Change: Migration as Adaption. Nature 2011, 478, 447-449. [CrossRef]

23. Penning-Rowsell, E.C.; Sultana, P.; Thompson, P.M. The 'Last Resort'? Population Movement in Response to Climate-Related Hazards in Bangladesh. Environ. Sci. Policy 2013, 27, 44-59. [CrossRef]

24. Foresight. Foresight: Migration and Global Environmental Change; The Government Office for Science: London, UK, 2011.

25. Berkes, F.; Ross, H. Community Resilience: Toward an Integrated Approach. Soc. Nat. Resour. 2013, $26,1-16$. [CrossRef]

26. Berkes, F.; Carl, F. Linking Social and Ecological Systems: Management Practices and Social Mechanisms for Building Resilience; Berkes, F., Folke, C., Eds.; Cambridge University Press: Cambridge, UK, 1998.

27. Auerbach, L.; Goodbred, S.; Mondal, D.R.; Wilson, C.A.; Ahmed, K.R.; Roy, K.; Steckler, M.S.; Small, C.; Gilligan, J.M.; Ackerly, B. Flood Risk of Natural and Embanked Landscapes on the Ganges-Brahmaputra Tidal Delta Plain. Nat. Clim. Chang. 2015, 5, 89-92. [CrossRef]

28. Bennet, K.; Bilak, A.; Bullock, N.; Cakaj, L.; Clarey, M. Global Report on Internal Displacement. 2017. Available online: http://www.internal-displacement.org/global-report/grid2017/pdfs/2017-GRID.pdf (accessed on 18 March 2018).

29. BBS. Statistical Year Book 2011; Bangladesh Bureau of Statistics, Government fo Bangladesh: Dhaka, Bangladesh, 2012.

30. Szabo, S.; Begum, D.; Ahmad, S.; Matthews, Z.; Streatfield, P.K. Scenarios of Population Change in the Coastal Ganges Brahmaputra Delta (2011-2051). Asia-Pac. Popul. J. 2015, 30, 51-72. [CrossRef]

31. Fabinyi, M.; Evans, L.; Foale, S. Social-Ecological Systems, Social Diversity, and Power: Insights from Anthropology and Political Ecology. Ecol. Soc. 2014, 19, 28. [CrossRef]

32. Adams, H.; Adger, W.N.; Ahmed, M.; Huq, H.; Rahman, R.; Salehin, M. Defining Social-Ecological Systems in South-West Bangladesh. In Ecosystem Services for Well-Being in Deltas, 1st ed.; Nicholls, R.J., Hutton, C.W., Adger, W.N., Hanson, S.E., Rahman, M.M., Salehin, M., Eds.; Palgrave Macmillan: London, UK, 2018; pp. 405-423.

33. Meerow, S.; Newell, J.P. Resilience and Complexity: A Bibliometric Review and Prospects for Industrial Ecology. J. Ind. Ecol. 2015, 19. [CrossRef]

34. Thompson, M. Migration Decision-Making: A Geographical Imaginations Approach. Area 2017, 49, 77-84. [CrossRef]

35. Adams, H. Why populations persist: Mobility, place attachment and climate change. Popul. Environ. 2016, 37, 429-448. [CrossRef] 
36. Mallick, B. Der Gesellschaftliche Umgang Mit Zunehmender Verwundbarkeit; Karlsruhe Institute of Technology (KIT): Karlsruhe, Germany, 2014.

37. Ayeb-karlsson, S. When the Disaster Strikes: (Im) Mobility Decision-Making in the Context of Environmental Shocks and Climate Change Impacts. Ph.D. Thesis, University of Sussex, Brighton, UK, 2018.

38. Martin, M.; Billah, M.; Siddiqui, T.; Abrar, C.; Black, R.; Kniveton, D. Climate-related migration in rural Bangladesh: A behavioural model. Popul. Environ. 2014, 36, 85-110. [CrossRef]

39. Harris, J.; Todaro, M. Migration, Unemployment and Development: A Two- Sector Analysis. Am. Econ. Rev. 1970, 60, 126-242.

40. Janssen, M.A.; Ostrom, E. Resilience, Vulnerability, and Adaptation: A Cross-Cutting Theme of the International Human Dimensions Programme on Global Environmental Change. Global Environ. Chang. 2006, 16, 237-239. [CrossRef]

41. Ahmed, N. Development of Integrated Prawn-Fish-Rice Farming for Sustainable Livelihoods of the Rural Poor in Southwest Bangladesh. World Aquac. 2009, 40, 35-41.

42. Ramaswami, A.; Weible, C.; Main, D.; Heikkila, T.; Siddiki, S.; Duvall, A.; Pattison, A.; Bernard, M. A Social-ecological-infrastructural Systems Framework for Interdisciplinary Study of Sustainable City Systems: An Integrative Curriculum Across Seven Major Disciplines. J. Ind. Ecol. 2012, 16, 801-813. [CrossRef]

43. Van der Leera, J.; van Timmeren, A.; Wandl, A. Social-Ecological-Technical systems in urban planning for a circular economy: An opportunity for horizontal integration. Archit. Sci. Rev. 2018, 61, 298-304. [CrossRef]

44. Subregion, G. Issues of Livelihood, Sustainable Development, and Governance: Bay of Bengal. Ambio 2014, 33, 34-44.

45. Lopez-Marrero, T.; Tschakert, P. From Theory to Practice: Building More Resilient Communities in Flood-Prone Areas. Environ. Urban. 2011, 23, 229-249. [CrossRef]

46. Etzold, B.; Mallick, B. Moving Beyond the Focus on Envrionmental Migration Towards Recognizing the Normality of Translocal Lives: Insights from Bangladesh. In Migration, Risk Management and Climate Change: Evidence and Policy Responses; Milan, A., Schraven, B., Warner, K., Cascone, N., Eds.; Global Migration Issues; Springer: Cham, Switzerland, 2017; pp. 105-128.

47. Peth, S.A.; Birtel, S. Translocal Livelihoods and Labor Migration Systems in Bangladesh. In Environment, Migration and Adaptation -Evidence and Politics of Climate Change in Bangladesh, 1st ed.; Mallick, B., Etzold, B., Eds.; AHDPH Publishing House, Dhaka: Dhaka, Bangladesh, 2015.

48. Keck, M.; Sakdapolrak, P. What Is Social Resilience? Lessons Learned and Ways Forward. Erdkunde 2013, 67, 5-19. [CrossRef]

49. Mallick, B.; Siddiqui, T. Disaster-Induced Migration and Adaptation Discourse in Bangladesh. In Environmental Change, Adaptation and Migration: Bringing in the Region; Hillmann, F., Pahl, M., Rafflenbeul, B., Sterly, H., Eds.; Palgrave and McLemann: London, UK, 2015.

50. Mallick, B. Necessity of Acceptance? Searching for a Sustainable Community-Based Disaster Mitigation Approach-The Example of a Coastal City in Bangladesh. In Proceedings of the Solutions to Coastal Disasters 2011-Proceedings of the 2011 Solutions to Coastal Disasters Conference, Anchorage, Alaska, 25-29 June 2011. [CrossRef]

(C) 2019 by the author. Licensee MDPI, Basel, Switzerland. This article is an open access article distributed under the terms and conditions of the Creative Commons Attribution (CC BY) license (http://creativecommons.org/licenses/by/4.0/). 